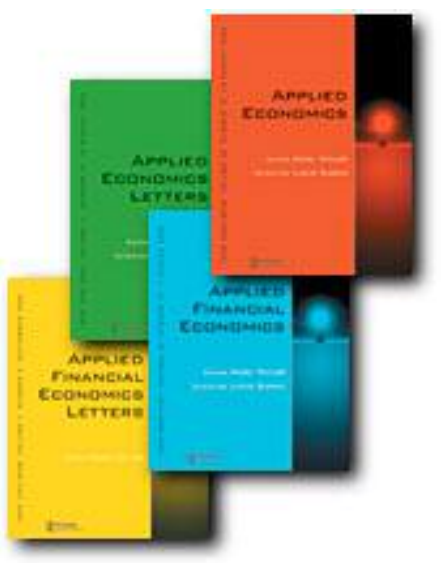

Current account composition and sustainability of external debt

\begin{tabular}{|r|l|}
\hline Journal: & Applied Economics \\
\hline Manuscript ID: & APE-06-0352.R1 \\
\hline Journal Selection: & Applied Economics \\
\hline JEL Code: & $\begin{array}{l}\text { E44 - Financial Markets and the Macroeconomy < E4 - Money and } \\
\text { Interest Rates < E - Macroeconomics and Monetary Economics, F34 } \\
\text { - International Lending and Debt Problems < F3 - International } \\
\text { Finance < F - International Economics }\end{array}$ \\
\hline Keywords: & Equity capital, FDI, CA deficit, external debt \\
\hline \multicolumn{2}{|l}{} \\
\hline
\end{tabular}

powered by ScholarOne

Manuscript Central ${ }^{\text {TH}}$ 


\title{
Current account composition and sustainability of external debt *
}

\author{
Gianpaolo Rossini ${ }^{\dagger}$ \\ Department of Economics, \\ University of Bologna, \\ Strada Maggiore, 45; \\ I-40125 Bologna, \\ Italy \\ rossini@spbo.unibo.it \\ Paolo Zanghieri \\ ANIA - Association of Italian Insurers, \\ Research Department, \\ via della Frezza, 70; \\ I-00186 Roma, \\ Italy \\ Paolo.Zanghieri@ania.it \\ Revised version \\ July 2006
}

\begin{abstract}
*We thank Michael Margolis for useful comments, the University of Bologna for the financial support within the $60 \%$ scheme for the a.y. 2006, ANIA and Piera Appoggi for statistical support. Paper presented at the EcoMod 2006, International Conference on Policy Modeling, Hong Kong, China, June 28-30, and at the 2006 ETSG Conference, Vienna, September 7-9.

${ }^{\dagger}$ Corresponding author; rossini@spbo.unibo.it; Fax: $\quad+390512092664 ; \quad \mathrm{Ph}$. +390512092607 .
\end{abstract}




\begin{abstract}
If an economy runs a current account (CA) deficit and finances it via a corresponding net inflow of equity capital the external debt (ED) of the country does not change, i.e.: the CA deficit does not add to ED. This is no paradox and simply comes from the definition of CA deficit and $\mathrm{ED}$ and points to different degrees of sustainability of CA deficits according to the way they are financed and to the composition of the CA itself.

By the evaluation of the determinants of interest rates spreads vis à vis US lending rates we assess the sustainability of CA deficits finding that FDI net inflows (proxy of equity capital) allow emerging economies to sustain imbalances larger with respect to CA deficits financed by inflows of more liquid assets. Equity capital as a way to finance the CA, not contributing to the ED, affects the solvency assessment of a country.
\end{abstract}

JEL Classification: E44, F34

Keywords: Equity capital, FDI, CA deficit, external debt. 


\section{Introduction}

History and literature tell happy end stories and tragedies brought about by current account (CA) imbalances and external debt (ED) of countries. Australia, Canada, Norway have run for decades CA deficits with no external crisis. South Korea, Indonesia, Thailand, between 1997 and 1998, and other countries involved in systemic crisis of the 1990s and 2000s paid a high price for CA deficits, despite the robustness of their economies, the low levels of imbalances and the short time during which external disequilibria occurred.

Several interpretations have been put forward to account for these divergent destinies. Most point to the short term financial exposition of countries and banks governance (Özmen, 2005) and to other structural features such as the weakness of financial institutions (Hahm, 2004) or unsustainable growth rates.

Recent literature (Beim and Calomiris, 2001; Lane, 2004, 2005; Lane and Milesi - Ferretti, 2005a, 2005b; Tang, 2006) investigates the sustainability of $\mathrm{CA}$ imbalances, focusing on the composition of CA and the way CA imbalances is financed. Great attention has been paid to capital income flows (interest and dividends) as signals of the sustainability of the ED, since the "financial items" of the CA provide hints as to the returns on gross foreign assets. This is a promising route to investigate the riskiness of a country and its international financial position. We proceed along this path concentrating on the role of equity capital flows and, in particular, FDI in emerging countries.

Equity capital and equity securities receive a particular treatment in the accounting of ED and this makes the effect of FDI, largely made by equity capital, on the solvency of a country rather special. Flows of FDI and equities, are recorded in the financial account (FA) of the balance of payments (BOP). But they do not contribute to the ED (IMF, 2000; 2003, chapter 2).

Consider the following example. First, suppose that the CA of Uganda shows a deficit of $10 \$$. Secondly, Uganda has a FA surplus of $10 \$$, entirely due to net equity ${ }^{1}$ inflow. Then, the BOP of Uganda is in equilibrium. Neither the exchange rate (ER) should move, in the case of flexible ER, nor foreign exchange reserve (FER) should vary, in the case of fixed ER.

\footnotetext{
${ }^{1}$ FDI includes roughly two kinds of flows: equities providing a company share larger than $10 \%$ and greenfield investment financing, that takes place when, for instance, a new plant of a Multinational firm is built in a foreign country. The first kind of flow does not enter the ED, while the second does.
} 
What happens to the ED? Nothing, since it stays constant and does not change as a result of the net inflow of $10 \$$ to buy Uganda equities. This inflow does not contribute to the ED of Uganda (IMF, 1993; 2000; 2003). The $10 \$$ worth equities in the hands of foreigners are a liability of Uganda. Nonetheless, these foreign liabilities do not contribute to the ED of Uganda. On the contrary, suppose Uganda had an inflow of $10 \$$ due to the purchase by foreigners of treasury Bonds of Uganda. The effect on the BOP would be the same. Yet, the ED of Uganda has worsened by $10 \$$, while before, with equities, it did not change.

Foreign inflows to buy equities do not affect the ED of an economy. What is the rationale of this seemingly inexplicable statistical taxonomy? It comes from the very nature of equities. In particular, FDI may finance with foreign funds the acquisition by a non-resident of a chunk of real capital (equity) which may not be much liquid and not immediately tradable (Rossini and Zanghieri, 2003). An equity does not imply a strict obligation to pay somebody back at any given date.

In extreme cases, the equilibrium of the $\mathrm{BOP}$ with recurrent $\mathrm{CA}$ deficits, may be secured by selling equities to foreigners. A country may run CA deficits for prolonged periods if inflows of equity capital finance it, as they do not impinge upon the ED.

Equity flows go into two distinct categories of the FA. The first is FDI, made up of two items: flows of "Equity Capital and Reinvested Earnings" and "Other Capital." The second is Portfolio Investment, whose components are "Equity securities" and "Debt Securities". The problem is that the accounting distinction between "Equity Capital and Reinvested Earnings" and "Other Capital" is not so clear-cut and may give rise to statistical misrecording.

The fact that a large portion of FDI does not add to the ED, will make the assessment of sustainability dependent upon the weight of FDI in the $\mathrm{FA}^{2}$.

Given all above considerations, our aim is to evaluate the relevance of FDI for the sustainability of CA deficits and the effect of FDI on variables signaling the degree of stress of the external position.

The paper is made up of two sections and an epilogue. In the next section

\footnotetext{
${ }^{2}$ For the particular nature of FDI and its influence of the saving available in an economy, see also Rossini and Zanghieri (2003) in a different perspective within the "Feldstein Horioka puzzle" literature.
} 
we go through solvency questions and the role of FDI. In the third section we dwell on econometric testing, while conclusions are in the epilogue.

\section{A reassessment of solvency}

Liquidity and solvency crises are often associated (Milesi-Ferretti and Razin, 1996) but they do not necessarily coincide. During systemic crisis, as in Asia (1997-1998), liquidity was the culprit. Solvency was not an issue except for Indonesia. Economies involved had liquid foreign liabilities and less liquid foreign assets, despite sustainable ED.

The equity paradox mentioned above impacts the solvency of a country. With inflows of equities, and in particular FDI, a country may be solvent while not liquid. With low equity flows it may be liquid but insolvent. Our view is that a solvent country is less risky than a liquid one: financial and monetary variables should reflect this.

We reassess solvency by extension of usual approaches (Obsfeld and Rogoff, 1996) to the determination of ratios that signal distress of the ED of an economy.

A signal of solvency is a stable ratio of ED over the GDP: agents are comfortable with stable ratios since they provide cushion for variability. We embrace this view even though it may not be entirely justified on theoretical grounds. We see whether proper accounting ${ }^{3}$ of equity flows - proxied by FDI - alters the ratio adopted in the literature and in policy evaluation. We use the intertemporal budget constraint (IBC) of an open economy, as in Obstfeld and Rogoff (1996). We assume that expenditure is made up of consumption $\left(C_{s}\right)$ and investment $\left(I_{s}\right)$ flows. Then the IBC, over an infinite horizon, is:

$$
\begin{gathered}
\sum_{s=t}^{\infty}\left(\frac{1}{1+r}\right)^{s-t}\left(C_{s}+I_{s}\right)= \\
=(1+r) B_{t}+(1-r) F_{t}+\sum_{s=t}^{\infty}\left(\frac{1}{1+r}\right)^{s-t}\left[Y_{s}+\left(F_{s+1}-F_{s}\right)(1-r)\right]
\end{gathered}
$$

\footnotetext{
${ }^{3}$ Adopted by international standards of the IMF (IMF, 1993; 2000; 2003) and the World Bank (World Bank, 2005).
} 
where $r$ stands for the common return on foreign assets (and liabilities) entirely repatriated each year ${ }^{4}$. $B_{t}$ is the net stock of foreign financial assets (short and long term) at time $t$ that contributes to the $\mathrm{ED}^{5} . F_{t}$ is the stock of home equities held by foreigners ${ }^{6}$ and represent a liability. But a special one, since they do not contribute to the ED, while they can be used to finance CA deficits. This is the core paradox of this paper.

The left hand side of (1) is the present value (PV) of aggregate expenditure.

The right hand side gives available resources. The first part is the stock of net foreign assets at the end of $t$, i.e.: $(1+r) B_{t}$. The second part is the stock of equities held by foreigners $F_{t}$ multiplied by $(1-r)$, since dividends are repatriated. This stock is a liability that may be used to pay imports by "selling capital." The third part shows the PV of future production $\left(Y_{s}\right)$ and equity sale flows to foreigners $\left(F_{s+1}-F_{s}\right)$.

Then we can write:

$-(1+r) B_{t}-(1-r) F_{t}=\sum_{s=t}^{\infty}\left(\frac{1}{1+r}\right)^{s-t}\left[Y_{s}-C_{s}-I_{s}+\left(F_{s+1}-F_{s}\right)(1-r)\right]$.

By standard notation (Obstfeld and Rogoff, 1996) the Trade Balance flow is:

$$
T B_{s}=Y_{s}-C_{s}-I_{s}
$$

while the "augmented" Trade Balance, including all resources that can be sold to foreigners, is:

$$
T R_{s}=T B_{s}+\left(F_{s+1}-F_{s}\right)(1-r) .
$$

Then we can write

$$
-\left(B_{t}+F_{t}\right)-r\left(B_{t}-F_{t}\right)=\sum_{s=t}^{\infty}\left(\frac{1}{1+r}\right)^{s-t} T R_{s},
$$

\footnotetext{
${ }^{4}$ This assumes away transaction costs which give rise to asymmetries between countries with CA surpluses vis à vis those with deficits (Obstfeld and Rogoff, 2000).

${ }^{5}$ This stock gives a return $r$ per period and, therefore, it is multiplied by $1+r$. International borrowing or lending may occur at any $t$ consistently with the IBC. If $B_{t}$ is negative it is a liability.

${ }^{6}$ Assets could be valued either at the acquisition price (or book value) or at their current value. The current price is not the value that the owner can obtain when selling if he has a large amount of the asset or if other agents follow him. $F_{t} \in[0, \infty)$.
} 
which is a stock - flow relationship.

Financial markets are keen on a stable ratio of ED on GDP as sign of low country risk. What is the cost of compliance with this requirement? Assume that GNP grows at a constant rate $g$. For a steady ED/GNP ratio $B_{t}$ must grow at the same speed $g$. In our scheme the increase in ED can be financed also via the "augmented" trade balance":

$$
\begin{aligned}
B_{s+1}-B_{s} & =g B_{s}=r B_{s}+T R_{s}= \\
& =r B_{s}+T B_{s}+\left(F_{s+1}-F_{s}\right)(1-r)
\end{aligned}
$$

or

$$
T B_{s}=-(r-g) B_{s}-\left(F_{s+1}-F_{s}\right)(1-r) .
$$

Dividing both sides by $Y_{S}$ we get:

$$
\frac{T B_{s}}{Y_{s}}=\frac{-(r-g) B_{s}-\left(F_{s+1}-F_{s}\right)(1-r)}{Y_{s}} .
$$

The usual definition of the burden of ED changes. The novelty? Trade surplus that a country needs to transfer in steady state to foreigners is reduced by equity inflows ${ }^{8}$. This alters the sustainability assessment of ED. We shall see empirically, in the next section, that equities make a difference. A country is more solvent the higher are equity sales to foreigners.

Equity sales reduce trade surpluses to pay back ED. Coeteris paribus, CA deficits have different effects on country risk according to the share of equity in their financing.

\section{The empirical evaluation}

Literature has provided measures of distress of ED (Beim and Calomiris, 2001; Manasse, Roubini and Schimmelpfennig, 2003; Ghosh and Ghosh, 2002). Widely used is the spread (SPR) between long term rates of interest in leading financial markets, i.e. the US, and those of the area under scrutiny. Since data on long term rates are not available for many emerging

\footnotetext{
${ }^{7}$ Consider an example: $B_{s+1}=-105 ; B_{s}=-100 ; g B_{s}=-5 ; r B_{s}=-10$.

Then the amount of resources to transfer to foreigners to keep a stable ED/Y ratio is equal to $T R_{s}=+5$.

${ }^{8}$ Notice that ED is a negative $B_{S}$. Therefore $F_{s+1}-F_{s}$ reduces the transfer to foreigners to keep ED stable.
} 
countries, we resort to lending rates. Emerging countries with ailing CAs over a long time span show higher interest rates $^{9}$. Even if there is no risk of sovereign default on external obligations, sheer international transaction costs put a wedge between the buying and selling price of saving on international markets. This is the SPR in interest rates that makes CA deficits costly for emerging countries (Obstfeld and Rogoff, 2000).

SPR is determined by the hindrances an economy faces as far as external accounts and imagine are concerned. Our aim is to see to what extent SPR is affected by FDI inflows and whether FDI is able to affect the signaling variable. Our prior is that SPR - the signal - decreases with larger net inflows of FDI. The adopted explanatory variable is net FDI inflow over the GDP i.e.: NFDI / GDPN in nominal terms. The higher is this variable the lower should be SPR.

Nonetheless, other variables jointly determine SPR.

The second variable is the relative inflation rate vis à vis the US, i.e.: INFL. We introduce INFL since we should compare real interest rates spreads. Inserting, among the explanatory variables of interest rates spread, INFL is equivalent to compare real interest rates spreads.

As a third variable, we use an indicator of growth of money supply (M2) called GRMON. Lougani and Swagel (2001) employ vector autoregressions (VARs) to study 53 developing countries between 1964 and 1998. They estimate VARs with the following variables: (i) money growth and exchange rates; (ii) the output gap and a measure of the world business cycle; (iii) changes in the price of oil and non-oil commodities; (iv) past realizations of inflation. Their findings suggest that either money growth or exchange rate movements - depending on the ordering - explain two-thirds of the variance of both short and long run inflation and, therefore, nominal interest rates. Moreover, money dynamics is commonly used in constructing leading indicators for inflation (Binner et al., 1999). Then, we expect that a larger money supply increases SPR.

The fourth variable is the ratio of Foreign Exchange Reserves over ED, i.e.: TRES/EXDB. The higher this ratio the lower should be SPR. A country is less liable to incur in liquidity crisis. The larger is the amount of reserves, vis à vis $\mathrm{ED}$, the higher is the ability to pay back short term obligations.

\footnotetext{
${ }^{9}$ This occurs also within quite homogeneous areas. For instance, transition in Eastern Europe began some 15 years ago, but nominal and real convergence has been achieved by quite few countiries ( Kasman, Kirbas-Kasman, Turgutlu, 2005).
} 
The fifth variable is the terms of trade, TOT, signaling competitiveness and, therefore, ability to pay back ED.

The sixth variable is a measure of health of real external accounts. It is the CA balance relatively to GDP (CAR). It is a prime indicator of a country economic imbalance on its foreign relationships. The better is the $\mathrm{CA}$, the lower will be SPR.

The seventh variable is a dummy, DLATAM, to separate Latin America from other areas. In that region specific sustainability criteria are adopted both by the countries themselves and by international investors.

The eighth variable is lagged real GDP in Logs, to capture the ability to grow and, therefore, to produce sufficient resources to pay back, via trade surpluses, ED.

Other explanatory variables are presented in the specific econometric exercise in which they are used. 


\subsection{TEST 1}

In the first test we use a static panel based on annual data over the period 1992-2003. In the first stage we run plain OLS estimation, detecting heteroschedasticity in the residuals. Then, we apply Estimated GLS, assuming that the error terms have components specific to each unit. This makes for a variance - covariance matrix with a clear block-diagonal structure that can be derived by the estimation of a small number of parameters.

The test is conducted for a group of countries made up of Indonesia, Malaysia, Philippines, India, Sri Lanka, Argentina, Bolivia, Brazil, Chile, Colombia, Costa Rica, Ecuador, Guatemala, Honduras, Mexico, Paraguay, Uruguay, Venezuela, Egypt, Jordan.

The results of the econometric tests are summarized in Table 1 below. 
Table 1

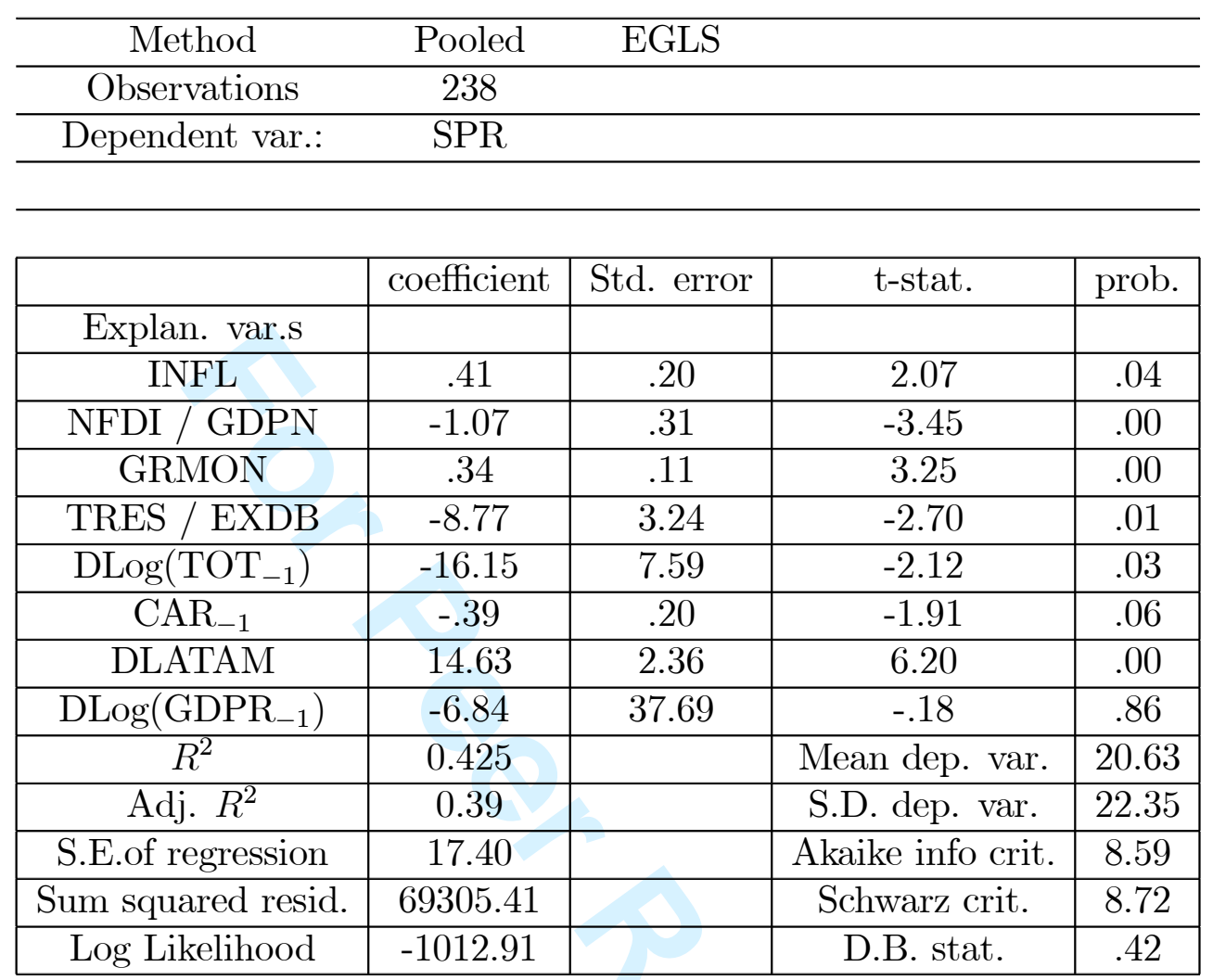




\section{COMMENTS}

From Table 1 we draw inferences as to the role of FDI and other variables in the explanation of SPR.

FDI plays the expected role reducing SPR - the dependent variable - which is the signal of stress in ED. The weight and significance of the coefficient confirm our theoretical prior that FDI helps a country to make ED lighter.

Expected signs show up in estimated coefficients of other variables. This is the case of the degree of international liquidity: the more liquid an economy is in terms of foreign exchange reserves, the lower is SPR.

Inflation contributes to SPR since it provides the nominal wedge between the interest rates of countries. Moreover, a looser monetary policy increases SPR as the coefficient of GRMON indicates. This result may seem odd at first sight. However, a larger money supply may lower real interest rates while increasing nominal interest rates in emerging countries with inflation. Here, we are indeed concerned with SPR between nominal interest rates. Our result confirm that in emerging countries loose monetary policies have increased SPR with respect to US rates.

Significant and relevant is the regional dummy whose high positive coefficient proves that Latin America is perceived as more risky and suffers a higher SPR than other regions.

The sign of the delayed TOT is at first sight puzzling. However, the association between a lower price of exports relatively to imports and a higher SPR is the result of exchange rates variations mirrored in the TOT. An exchange rate devaluation makes for lower export prices and higher import prices and it is associated to larger SPR.

Finally, the worse is the CA the higher is SPR. A result which confirms canonic priors. 


\section{$3.2 \quad$ TEST 2}

In the second test reported in Table 2 we turn to an enlarged sample of countries. The previous group is supplemented by Eastern Europe. Some countries now belong to enlarged EU as from May 2004. Our investigation is not affected since the time span is 1992-2003. New entries in the sample are Bulgaria, Russia, Czech Republic, Estonia, Latvia, Lithuania, Poland, Slovakia, Slovenia.

Here we introduce fixed effects. The different sample and estimation method lead to a fresh specification with some changes in the explanatory variables. FDI is now utilized relatively to the $\mathrm{CA}$ balance, both measured in local currency (NFDI / CAL). We also add the variable DLog(XN) which stands for rate of growth of the value of exports at current prices. Finally we use a constant (C) as the estimation is carried out with fixed effects. 
Table 2

\begin{tabular}{cccc}
\hline Method & Pooled & EGLS & Fixed effects \\
\hline Observations & 358 & & \\
\hline Dep.var.: & SPR & & \\
\hline
\end{tabular}

\begin{tabular}{|c|c|c|c|c|}
\hline & coefficient & Std. error & t-stat & prob. \\
\hline Explan. var.s & & & & \\
\hline INFL & .21 & .09 & 2.18 & .03 \\
\hline NFDI / CAL & -.04 & .01 & -2.19 & .03 \\
\hline GRMON & .19 & .05 & 4.01 & .00 \\
\hline DLog (XN) & -7.25 & 2.18 & -3.33 & .00 \\
\hline DLog (GDPR) & -.37 & .23 & -1.56 & .11 \\
\hline CAR $_{-1}$ & -.03 & .04 & -.76 & .45 \\
\hline C $_{R^{2}}$ & 18.68 & 5.33 & 3.50 & .00 \\
\hline Adj. $R^{2}$ & 0.83 & & Mean dep. var. & 44.99 \\
\hline S.E.of regression & 21.12 & & S.D. dep. var. & 44.46 \\
\hline Sum squared resid. & 143218.2 & & D.B. stat. & 1.01 \\
\hline \multicolumn{2}{|r|}{} & & F - stat. & 42.29 \\
\hline
\end{tabular}




\section{COMMENTS}

With a sample containing also emerging European countries results change slightly, while the effect of FDI on SPR maintains the expected sign. New variables, like exports, improve data fit. ${ }^{10}$ All previous variables keep their sign, yet with different significance. This is the case of the CA balance (CAR) that is losing grip, crowded out by Exports.

As a partial conclusion, the role of FDI in the explanation of the sufferance signal (SPR) is still crucial, proving our theoretical supposition. The extension to Eastern Europe means that FDI improves sustainability of ED also in areas which are more integrated and financially close to the EU. ${ }^{11}$

\footnotetext{
${ }^{10}$ The marked improvement in the $R^{2}$ is due to both the different set of regressors chosen and to the use of fixed effects.

${ }^{11}$ The same analysis we are conducting for emerging countries cannot be carried out in Euroland, since the SPR is quite compressed by the collateral policies of the ECB that tends to equalize interest rates all across the Euro area (see Buiter and Sibert, 2005).
} 


\subsection{TEST 3}

Here we consider a different sample of countries grouped according to their presumed similarity as far as the role of FDI in financing CA imbalances is concerned. We keep the economies of Test 2 excluding those belonging to Middle East and Asia.

The rationale lies in macroeconomic affinities existing between Latin America and Eastern Europe, concerning external variables. Moreover, Latin America has gone through a transition, during the 1990s, similar to Eastern Europe, from highly regulated and protected (sometimes semi-autarkic) structures to quite open and flexible markets. 
Table 3

\begin{tabular}{|c|c|c|c|c|}
\hline Method & Pooled & EGLS & \multicolumn{2}{|l|}{ Fixed effects } \\
\hline Observations & \multicolumn{4}{|l|}{252} \\
\hline \multirow[t]{2}{*}{ Dep. var.: } & \multicolumn{4}{|l|}{ SPR } \\
\hline & coefficient & Std. error & t-stat & prob. \\
\hline \multicolumn{5}{|l|}{ Expl. var.s } \\
\hline $\mathrm{C}$ & 20.37 & 4.39 & 4.63 & .00 \\
\hline INFL & .21 & .05 & 4.44 & .00 \\
\hline NFDI / GDPN & -.07 & .03 & -2.45 & .01 \\
\hline GRMON & .32 & .06 & 4.81 & .00 \\
\hline DLog(GDPR) & -85.06 & 22.55 & -3.77 & .00 \\
\hline DLog (TOT) & 1.39 & 8.28 & .16 & .87 \\
\hline CAR & -.19 & .24 & -.77 & .44 \\
\hline NFALC/GDPLC & 4.20 & 11.97 & .35 & .73 \\
\hline$R^{2}$ & 0.81 & & Mean dep var & 50.02 \\
\hline Adj. $R^{2}$ & 0.79 & & SD dep var & 50.71 \\
\hline S.E.of regression & 24.93 & 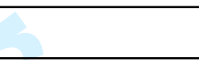 & prob (F-stat) & .00 \\
\hline Sum squared resid & 136688.7 & & & \\
\hline F-stat & 30.76 & & DB stat & 1.21 \\
\hline
\end{tabular}




\section{COMMENTS}

Here we have a new variable: net financial assets over GDP at current local prices. Changing the set of explanatory variables and a more targeted sample with countries displaying more homogeneous behavior does not eliminate the influence of FDI. The coefficient has the expected sign. In all cases FDI seems to reassure markets with a positive influence on the reduction of SPR.

The inclusion of fixed effects, changed specification and different sample may alter the importance of FDI as an inverse determinant of SPR. Nonetheless, the influence is always significant and of the expected sign. 


\section{Epilogue}

The aim is to reassess the role of equity, proxied by FDI, on ED. Equities appear in two sections of the FA of the BOP. Equity inflows finance the CA deficit of an economy as any other inflow of financial assets. Unlike other financial assets, equity does not contribute to ED, as dictates the International code for the compilation of external accounts. In the extreme case, a country can run CA deficits for ever without worsening its ED, if it can sell a sufficient amount of equity to foreigners.

This taxonomy is no fiction and comes from the very nature of equity sold to foreigners which represent pieces of an economy which are the property of nonresidents.

We add some flesh to this statement by showing theoretically and empirically that markets regard equity, and its proxy FDI, as a special "asset" without a definite obligation to pay back the holder. Equity reduces the amount of resources a country has to give to foreigners via Trade Balance surpluses to reimburse ED.

The empirical proof comes from three tests on panels of emerging countries during "hot" 1990s. In all tests FDI net inflows reduce SPR between lending rates of US and emerging countries. SPR is a widely used indicator of distress of the external position and risk of a country. Differences appear according to the sample we consider.

When Latin America and Asia are included we notice a strong effect of FDI on the reduction of SPR. Latin America suffered larger idiosyncratic SPR due to weak financial system. In this sense similarities with Eastern Europe emerge (Test 3). Both areas, during the 1990s, have undergone a transition process which turned them from quite closed and regulated into financially open economies, increasingly integrated with the rest of the world.

Further variables affect SPR. Their coefficients mostly behave in an orthodox manner. None of them crowds out or reverses the expected effect of FDI on the SPR. 


\section{References}

[1] Beim, David, and Charles Calomiris, 2001, Emerging Financial Markets. New York, McGraw-Hill.

[2] Binner, Jane, M. , Antony Fielding and Andy W. Mullineux, 1999, "Divisia money in a composite leading indicator of inflation," Applied Economics, 31, 1021- 1031.

[3] Buiter, Willem, H. and Anne Sibert, 2005, "How the Eurosystem's Treatment of Collateral in its Open Market Operations weakens Fiscal Discipline in the Eurozone (and what to do about it)," CEPR WP No. 5387.

[4] Ghosh, Swati, and Atish Ghosh, 2002, "Structural Vulnerabilities and Currency Crisis," IMF WP No. 02/9. Washington, International Monetary Fund.

[5] Hahm, Joon-Ho, 2004, "Interest rate and exchange rate exposures of banking institutions in pre-crisis Korea," Applied Economics, 36, 14091419.

[6] IMF (1993) Balance of payments manual. 5th Ed. Washington.

[7] IMF (2000) "Background Paper. Conference on Capital Flow and Debt Statisitcs: can we get Better Data Faster?" Washington D.C., February 23-24, 2000.

[8] IMF (2003) "External Debt Statistics: Guide for Compilers and Users." Washington DC, IMF.

[9] Kasman, Adnan; Kirbas-Kasman, Saadet; Turgutlu, Evrim, 2005, "Nominal and real convergence between the CEE countries and the EU: a fractional cointegration analysis", Applied Economics, 37, 2487-2500.

[10] Lane, Philip, 2004, "The Macroeconomics of International Financial Trade". In: Driver, Rebecca, Sinclair, Peter, Thoenissen, Christoph, eds. "Exchange Rates and Capital Movements". Routledge, London.

[11] Lane, Philip, 2005, "Global Bond Portfolios and EMU," ECB WP n.553. 
[12] Lane, Philip and Gian Maria Milesi-Ferretti, 2005 a, "Financial Globalization and Exchange Rates". IMF WP/05/03.

[13] Lane, Philip and Gian Maria Milesi-Ferretti, 2005 b, "A Global Perspective on External Positions". IMF WP/05/161.

[14] Lougani, Prakash and Phillip Swagel, 2001, "Sources of Inflation in Developing Countries", IMF Working Paper, No: WP/01/198.

[15] Manasse, Paolo, Nouriel Roubini and Axel Schimmelpfennig, 2003, "Predicting Sovereign Debt Crises". IMF WP No. 03/221.

[16] Milesi-Ferretti, Gian Maria and Assaf Razin, 1996, "Current - Account Sustainability", Princeton Studies in International Finance, No. 81.

[17] Min, Hong, G., 1998, "Determinants of Emerging Market Bond Spread: do Economic Fundamentals Matter?" World Bank Policy Research WP. No. 1899.

[18] Obstfeld, Maurice, and Kenneth Rogoff, 1996, Foundations of International Macroeconomics. Cambridge MA, MIT Press.

[19] Obstfeld, Maurice, and Kenneth Rogoff, 2000, "Six Puzzles in International Macroeconomics", NBER WP No. r7rry.

[20] OECD, 2004 and various years, Main Economic Indicators. Paris, OECD.

[21] Özmen, Erdal, 2005, "Macroeconomic and institutional determinants of current account deficits". Applied Economics Letters, 12, 557-560.

[22] Rossini, Gianpaolo and Paolo Zanghieri, 2003, "A Simple Test of the Role of Foreign Direct Investments in the Feldstein-Horioka puzzle." Applied Economics Letters, 10, 39-42.

[23] Tang, Tuck Cheong, 2006, "A new approach to examining the sustainability of external imbalances: the case of Japan," Applied Economics Letters, 13, 287-292.

[24] World Bank, 2005, "How to do a Debt Sustainability Analysis for LowIncome Countries." WB report No. 35620.

[25] World Bank, 2005, “World Development Indicators.” Washington. 